\title{
Length-Weight and Length-Length Relationships of Archer and Puffer Fish Species
}

\author{
K. D. Simon ${ }^{1}$ and A. G. Mazlan ${ }^{2 *}$ \\ ${ }^{I}$ Marine Science Programme, School of Environmental and Natural Resource Sciences, Faculty of Science and Technol- \\ ogy, National University of Malaysia, UKM, 43600, Bangi, Selangor D. E., Malaysia; ${ }^{2}$ Marine Ecosystem Research \\ Centre, Faculty of Science and Technology, National University of Malaysia, UKM, 43600, Bangi, Selangor D. E., Ma- \\ laysia
}

\begin{abstract}
Length-weight and length-length relationships are presented for four fish species from the estuaries of south Johore, Peninsular Malaysia. The values of the exponent $b$ in the length-weight relationships $(\mathrm{LWRs}) \mathrm{W}=\mathrm{aL}^{\mathrm{b}}$ ranged from 2.97 to 3.44 and length-length relationships (LLRs) $\mathrm{TL}=\mathrm{aSL}^{\mathrm{b}}$ ranged from 0.87 to 0.95 . The application of these regressions should be limited to the observed length ranges. The condition factor $\mathrm{K}$ was judged to be less important in comparative studies, since this parameter was closely correlated with $b$. To our knowledge the length-weight and length-length relationships presented herein for both archer fish (Toxotes chatareus and Toxotes jaculatrix) and puffer fish (Lagocephalus wheeleri and Lagocephalus sceleratus) species collected from study area represents the first reference available in Malaysian waters.
\end{abstract}

Key Words: Length-weight relationships, Length-length relationships, Archer fish, Puffer fish.

\section{INTRODUCTION}

Standing stock, yield and biomass are frequently estimated from length frequency data converted with lengthweight relationships (termed LWRs) and length-length relationships (termed LLRs) are useful for standardization of length type when data are summarized [1]. Moreover, the LWRs allow fish condition to be estimated. The condition factor (either $\mathrm{K}$ or $\mathrm{K}_{\mathrm{n}}$ ) is frequently used in the analysis of ontogenetic changes [2] and for between-regions life-history comparisons [3,4].

The relationship between the length (L) and weight (W) of a fish is usually expressed by the equation $\mathrm{W}=\mathrm{aL}^{\mathrm{b}}$. Values of the exponent ' $b$ ' provide information on fish growth. When $b=3$, increase in weight is isometric. When the value of $b$ is other than 3 , weight increase is allometric (positive if $\mathrm{b}>3$, negative if $\mathrm{b}<3$ ). This parameters $(\mathrm{a}, \mathrm{b})$ are important in stock assessment studies $[1,5,6]$.

LWRs and LLRs data are available for most European and North American estuarine fishes, while these data are unavailable in tropical fish species. The present study describes the LWRs and LLRs of two archer fish ( $T$. chatareus and $T$. jaculatrix) and two puffer fish species ( $L$. wheeleri and $L$. sceleratus) caught in Malaysian estuaries.

\section{MATERIALS AND METHODOLOGY}

Samplings of the fishes were carried out in the estuaries of south Johore, Peninsular Malaysia between the years 2006 and 2007. Samples were collected using 3 layered trammel

*Address correspondence to this author at the Marine Ecosystem Research Centre, Faculty of Science and Technology, National University of Malaysia, UKM, 43600, Bangi, Selangor D. E., Malaysia; Tel: +60389213219; Fax; +60389253357; E-mail: magfish05@yahoo.com net, cast and scoop nets, traps as well as long lines. The mesh sizes of the trammel and cast nets were 4.2, 6.5, 7.5 and $2 \mathrm{~cm}$ respectively and of the scoop nets $1.5 \mathrm{~cm}$. The length of the trammel net was $2000 \mathrm{~cm}, 250 \mathrm{~cm}$ for cast net and $40 \mathrm{~cm}$ diameter for scoop net. After hauling, the catch was removed, and the fish were preserved in $10 \%$ buffer formaldehyde for subsequent analysis in the laboratory. In the laboratory all fish were measured for their total and standard length to the nearest $0.01 \mathrm{~cm}$ with a measuring board and weighed to the nearest $0.01 \mathrm{~g}$ accuracy using an electronic balance.

To compare length and weight for a particular sample or individual, condition factors are used [2]. One is the Fulton's condition factor $(\mathrm{K})$, equal to $\mathrm{W} / \mathrm{L}^{3}$ [7] while other one is relative condition factor $\left(\mathrm{K}_{\mathrm{n}}\right), \mathrm{Kn}=\mathrm{W} / \mathrm{aL}^{\mathrm{b}}$. In our study we used more homogenous formula of condition factor $\mathrm{K}=1000 \mathrm{~W} / \mathrm{L}^{3}$, to know the growth condition of fish [8]. In addition, we conducted the prediction test to examine relationship between relative condition factor (i.e. a ratio of observed weight to predicted weight) with total length (TL).

In the present study, the LWRs were calculated using the formula: $\mathrm{W}=\mathrm{aL}^{\mathrm{b}}$ [9]. Whereas $\mathrm{W}$ (Weight) is independent and $\mathrm{L}$ (Length) is dependent variable, ' $\mathrm{a}$ ' is an intercept and ' $b$ ' is power function. LLRs were established using the formula of $T L=a S L$. Determination of ' $a$ ' and ' $b$ ' values were performed using a non-linear regression of which the curves fitting were carried out by chi-square $\left(\chi^{2}\right)$ iterative methods using Levenberg-Marquardt and Simplex algorithms readily developed in MicroCalc. Origin ${ }^{\mathrm{TM}}$ Version 6.0 computer software.

\section{RESULTS AND DISCUSSION}

The sample size, the minimum, maximum and mean length $( \pm$ S.E. $)$, the minimum and maximum weight meas- 
Table 1. Length-Weight Relationships and Related Statistics of 4 Fish Species

\begin{tabular}{|c|c|c|c|c|c|c|c|c|c|c|c|c|c|c|}
\hline \multirow{2}{*}{ Species $^{\mathrm{a}}$} & \multirow{2}{*}{$\begin{array}{c}\text { Sample } \\
\text { Size, } n\end{array}$} & \multirow{2}{*}{ Length $^{b}$} & \multicolumn{4}{|c|}{ Length Characteristics } & \multicolumn{2}{|c|}{$\begin{array}{c}\text { Weight } \\
\text { Characteristics }^{\mathrm{e}}\end{array}$} & \multicolumn{6}{|c|}{ Parameter of the Relationships ${ }^{\mathrm{d}}$} \\
\hline & & & Mean & S.E. & Min. & Max. & Min. & Max. & $\mathbf{a}$ & S.E. (a) & b & S.E. $(\mathbf{b})$ & $x^{2}$ & $\mathbf{r}^{2}$ \\
\hline \begin{tabular}{c}
\multicolumn{1}{c}{$T}$. \\
chatareus \\
$(1,2,3,4,5)$
\end{tabular} & 63 & $\mathrm{TL}$ & 14.29 & \pm 0.347 & 9.8 & 22.5 & 13.33 & 270.20 & 0.0059 & \pm 0.0014 & $3.44 \mathrm{P}$ & \pm 0.0798 & 69.114 & 0.967 \\
\hline $\begin{array}{c}T . \\
\text { jaculatrix } \\
(1,2,3,4,5)\end{array}$ & 65 & $\mathrm{TL}$ & 14.96 & \pm 0.319 & 8.7 & 23.0 & 13.41 & 275.31 & 0.0078 & \pm 0.0019 & $3.31 \mathrm{P}$ & \pm 0.0847 & 69.045 & 0.953 \\
\hline $\begin{array}{l}\text { L. wheeleri } \\
\text { (1) }\end{array}$ & 84 & $\mathrm{TL}$ & 19.78 & \pm 0.278 & 10.2 & 24.0 & 21.61 & 260.00 & 0.0204 & \pm 0.0022 & $2.97 \mathrm{~N} / \mathrm{I}$ & \pm 0.0365 & 22.372 & 0.991 \\
\hline $\begin{array}{c}L . \\
\text { sceleratus } \\
\text { (1) }\end{array}$ & 148 & $\mathrm{TL}$ & 13.57 & \pm 0.097 & 11.2 & 18.3 & 13.41 & 275.31 & 0.0133 & \pm 0.0039 & $2.99 \mathrm{~N} / \mathrm{I}$ & \pm 0.1121 & 26.628 & 0.776 \\
\hline
\end{tabular}

${ }^{a}$ Fishing gear: (1) trammel net; (2) cast net; (3) scoop net; (4) Trap; (5) Line.

${ }^{b}$ Length (in $\mathrm{cm}$ ) of the species is expressed as total length.

${ }^{\mathrm{c}}$ Weight (in g) of the species is expressed as total body weight.

${ }^{\mathrm{d}}$ Kind of growth : I, isometry; P, positive allometry; N, negative allometry.

Table 2. Parameters of Length-Length Relationships of 4 Fish Species

\begin{tabular}{|c|c|c|c|c|c|c|c|c|c|c|c|c|c|c|c|}
\hline \multirow[b]{2}{*}{ Species } & \multirow{2}{*}{$\begin{array}{c}\text { Sample } \\
\text { Size, } n\end{array}$} & \multicolumn{4}{|c|}{ Total Length Characteristics } & \multicolumn{4}{|c|}{ Standard Length Characteristics } & \multicolumn{6}{|c|}{ Parameter of the Relationships } \\
\hline & & Mean & S.E. & $\begin{array}{l}\text { Min. } \\
\text { (cm) }\end{array}$ & $\begin{array}{l}\text { Max. } \\
\text { (cm) }\end{array}$ & Mean & S.E. & $\begin{array}{l}\text { Min. } \\
\text { (cm) }\end{array}$ & $\begin{array}{l}\text { Max. } \\
\text { (cm) }\end{array}$ & $\mathbf{a}$ & S.E. (a) & b & S.E. (b) & $\chi^{2}$ & $\mathbf{r}^{2}$ \\
\hline $\begin{array}{c}T . \\
\text { chatareus }\end{array}$ & 63 & 14.29 & \pm 0.347 & 9.8 & 22.5 & 12.64 & \pm 0.318 & 8.3 & 19.0 & 1.3158 & \pm 0.1007 & 0.9408 & \pm 0.0292 & 0.4225 & 0.9453 \\
\hline $\begin{array}{c}T . \\
\text { jaculatrix }\end{array}$ & 65 & 14.96 & \pm 0.319 & 8.7 & 23.0 & 12.88 & \pm 0.307 & 7.0 & 21.0 & 1.6219 & \pm 0.1026 & 0.8700 & \pm 0.0242 & 0.2947 & 0.9562 \\
\hline $\begin{array}{c}L . \\
\text { wheeleri }\end{array}$ & 84 & 19.78 & \pm 0.278 & 10.2 & 24.0 & 19.17 & \pm 0.279 & 9.6 & 23.5 & 1.1713 & \pm 0.0457 & 0.9572 & \pm 0.0131 & 0.0813 & 0.9876 \\
\hline $\begin{array}{c}L . \\
\text { sceleratus }\end{array}$ & 148 & 13.57 & \pm 0.097 & 11.2 & 18.3 & 13.03 & \pm 0.097 & 10.7 & 17.9 & 1.1571 & \pm 0.0179 & 0.9588 & \pm 0.0060 & 0.0087 & 0.9937 \\
\hline
\end{tabular}

ured, the LWR parameters a and b, the standard error of the slope, the calculated value of $\chi^{2}$, and the coefficient of determination, $\mathrm{r}^{2}$ are presented in Table $\mathbf{1}$. Information on the kind of growth (isometric or allometric) of each species is furnished, as well as the type of the fishing gears deployed. LLRs parameters and growth conditions are presented in Table $\mathbf{2}$ and Table $\mathbf{3}$.

In our study we observed that there was variability between the exponent ' $b$ ' and means of condition factors $(K$, $\mathrm{K}_{\mathrm{n}}$ ), for both archer and puffer fish (Table 3). These differences might have been caused by the methods of measurements, and /or seasonal fluctuations, or variability in sampling. Nevertheless, the numerical values of $\mathrm{K}$ are not so important, since $\mathrm{K}$ is closely correlated with ' $\mathrm{b}$ '. As a matter of fact, for applied ichthyological studies, only ' $b$ ' seems to be important as a key parameter in estimating population growth through length-weight relationship [2,10].

Though our results showed that the values of ' $b$ ' were less than 3 or nearly isometric $(b=3)$ in both species of puffer fish, whereas in archer fish all remaining values of ' $b$ ' were greater than 3 (Table 1). The median value of ' $b$ ' was 3.14 (Fig. 1). The ' $b$ ' value above 3 indicates that fish become wider or deeper as they grow while an exponent below 3 indicates they become more slender. An isometric growth would characterize a fish of unchanging body form and unchanging specific gravity [2].

Our results are analogous with the range of values of this parameter usually encountered in fin fishes, which lies between 2 and 4 according to Bagenal and Tesch [11]. Recently, Froese [12] confirmed the suggestion of Carlander [13] that the exponent ' $b$ ' should normally fall between 2.5 and 3.5 .

The chi square $\left(\chi^{2}\right)$ iterative method used in this study showed that there were no significant differences between the observed values and predicted values of the LWRs and LLRs models for both species of fishes (Table $\mathbf{1}$ and 2). LWRs parameters may vary significantly due to biological and environmental conditions or geographical, temporal and 
Table 3. Growth Conditions of Four Fish Species

\begin{tabular}{|c|c|c|c|c|c|}
\hline \multirow{2}{*}{ Species } & \multicolumn{5}{|c|}{ Growth Conditions } \\
\hline & $\mathbf{W}=\mathbf{a} \mathbf{L}^{\mathbf{b}}$ & Mean & S.E (K) & Mean & S.E. $\left(\mathbf{K}_{\mathbf{n}}\right)$ \\
\hline T. chatareus & $\mathrm{W}=0.0059 \mathrm{~L}^{3.4395}$ & 19.347 & \pm 0.3461 & 1.483 & \pm 0.261 \\
\hline T. jaculatrix & $\mathrm{W}=0.0078 \mathrm{~L}^{3.31}$ & 18.552 & \pm 0.2774 & 1.830 & \pm 0.391 \\
\hline L. sceleratus & $\mathrm{W}=0.01332 \mathrm{~L}^{2.9907}$ & 13.057 & \pm 0.2008 & 0.881 & \pm 0.066 \\
\hline
\end{tabular}

sampling factors $[11,12]$. These factors were not considered in the present study. However, our research provides the first references on length-weight and length-length relationship of these fish species in Malaysian coastal waters.

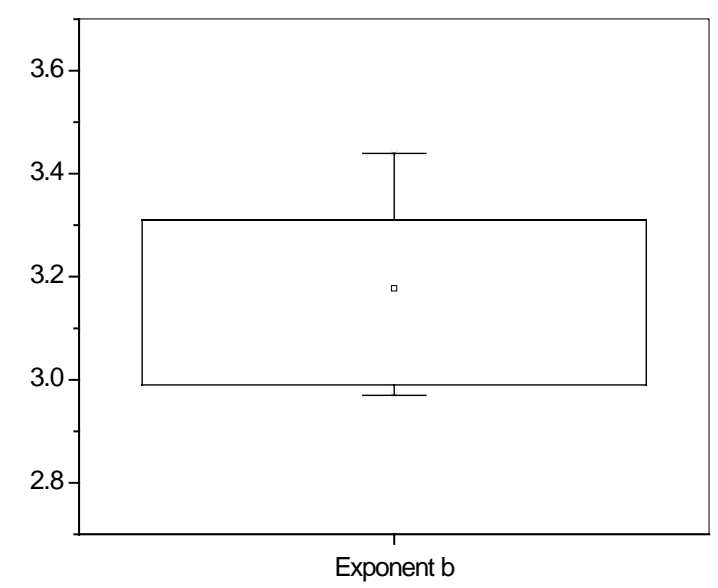

Fig. (1). Box-whisters plots of the exponent ' $b$ ' of the length-weight relationships $\left(\mathrm{W}=\mathrm{aL}^{\mathrm{b}}\right)$ for 4 fish species caught in the study area. The box covers $50 \%$ of the data values. The central box shows the median, and the vertical line represents the range of values.

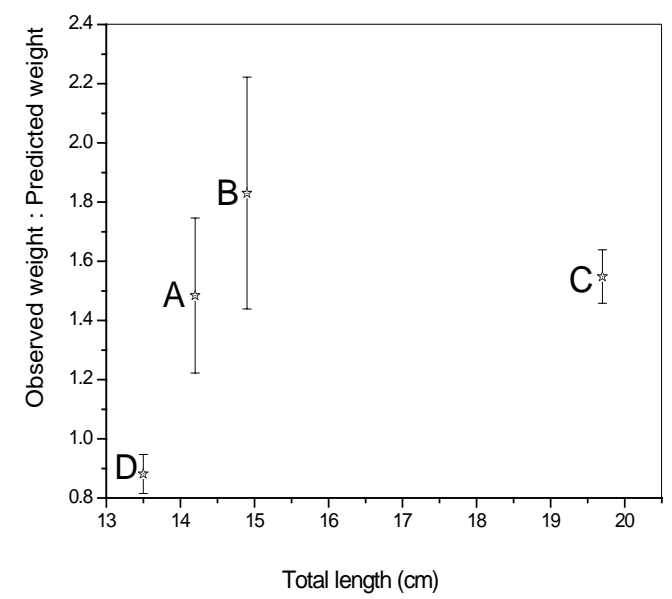

Fig. (2). Prediction test: Prediction error for four fish species $(\mathrm{A}=T$. chatareus, $\mathrm{B}=T$. jaculatrix, $\mathrm{C}=$ L. wheeleri, $\mathrm{D}=$ L. sceleratus $)$. For each analysis, the measured length of sample used at least 60 individual fish of each species.

The prediction test generally involved evaluating the bias in equation and the variance component in equation. Our results indicate that there were no differences in prediction values of relative condition factor of archer fish (Fig. 2). However there were marked differences of similar analyses between two species of puffer fish as shown in Fig. 2. This was probably due to the fact that the adult L. sceleratus was relatively smaller than that of $L$. wheeleri [14].

\section{CONCLUSIONS}

The population growth of four species of fishes showed that archer fish species demonstrated a positive allometric growth where as the puffer fish species demonstrated near isometric population growth conditions. However there were variabilities between the conditions factors measured that might have been caused by several environmental and technical differences.

\section{ACKNOWLEDGEMENTS}

This study was funded by the Malaysia government through a Science Fund grant 04-01-02-SF0124. The authors would like to express their special thanks to all dedicated laboratory technicians for their help in collecting fish used in this study.

\section{REFERENCES}

[1] Froese R. Length-weight relationships for 18 less-studied fish species. J Appl Ichthyol 1998; 14: 117-118.

[2] Safran P. Theoretical analysis of the weight-length relationships in the juveniles. Mar Biol 1992; 112: 545-551.

[3] Petrakis G, Stergiou KI. Weight-length relationships for 33 fish species in Greek waters. Fish Res 1995; 21: 465-469.

[4] Weatherley AH, Gill HS. The Biology of Fish Growth. Academic Press: London 1987.

[5] Can MF, Basusta N, Cekic M. Weight-length relationships for selected fish species of the small-scale fisheries off the south coast of Iskenderun Bay. Turk J Vet Anim Sci 2002; 26: 1181-1183.

[6] Moutopoulos DK, Stergiou KI. Length-weight and length-length relationships of fish species from Aegean Sea (Greece). J Appl Ichthyol 2002; 18: 200-203.

[7] Fulton TW. The Sovereignty of the Sea. Blackwood: Edinburgh 1911.

[8] Bauchot R, Bauchot ML. Coefficient de condition at indice ponderal chez les Teleosteens. Cybium 1978; 3: 3-16.

[9] Pauly D. Fish population dynamics in tropical waters. A Manual for Use with Programmable Calculators. ICLARM Studies and Reviews 8. International Center for Living Aquatic Resources Management, Manila, Philippines 1984.

[10] Kimmerer W, Avent SR, Bollens SM, Feyrer F, Grimaldo FL, Moyle PB, Nobriga M, Visintainer T. Variability in Length-Weight Relationships used to estimate biomass of estuarine fish from survey data. Trans Am Fish Soc 2005; 134: 481-495. 
[11] Bagenal TB, Tesch FW. Age and growth. In: Bagenal, T.B. (ed), Methods for assessment of fish production in freshwater, $3^{\text {rd }}$ ed. Blackwell Scientific Publication: Oxford, UK 1978.

[12] Froese R. Cube law, condition factor and weight-length relationships: history, meta-analysis and recommendations. J Appl Ichthyol 2006; 22: 241-253.
[13] Carlander KD. Handbook of freshwater fishery biology Vol. 1. The Iowa State University Press: USA 1969.

[14] Sabrah MM, El-Ganainy AA, Zaky MA. Biology and toxicity of the pufferfish Lagocephalus sceleratus (Gmelin, 1789) from the Gulf of Suez. Egypt J Aqua Res 2006; 32: 283-297.

Received: March 14, 2008

Revised: April 01, 2008

Accepted: April 03, 2008

(C) Simon and Mazlan; Licensee Bentham Open.

This is an open access article distributed under the terms of the Creative Commons Attribution License (http://creativecommons.org/licenses/by/2.5/), which permits unrestrictive use, distribution, and reproduction in any medium, provided the original work is properly cited. 